\title{
Novel 2-hydroxyethyl substituted $N$-coordinate-Pd(II)(NHC) and bis(NHC)Pd(II) complexes: Synthesis, characterization and the catalytic activity in the direct arylation reaction
}

\author{
AYDıN AKTAŞ, ${ }^{\mathrm{a}, *}$ (1), DUYGU BARUT CELEPCI ${ }^{\mathrm{b}}$ and YETKIN GÖK ${ }^{\mathrm{a}}$ \\ ${ }^{a}$ Faculty of Science, Department of Chemistry, İnönü University, 44280 Malatya, Turkey \\ ${ }^{\mathrm{b}}$ Faculty of Sciences, Department of Physics, Dokuz Eylül University, 35160 Buca, İzmir, Turkey \\ E-mail: aydinaktash@hotmail.com
}

MS received 12 April 2019; revised 13 June 2019; accepted 17 June 2019

\begin{abstract}
The direct arylation reaction has attracted attention in recent years especially because of its environment-friendly properties. In this study, we researched the synthesis of 2-hydroxyethyl substituted bis(NHC)Pd(II) complexes and also the synthesis of $N$-coordinate-Pd(II)(NHC) complexes containing $N$ bound benzimidazolium from palladium acetate $\left(\left[\mathrm{Pd}\left(\mathrm{CH}_{3} \mathrm{COO}\right)_{2}\right]\right)$ with 1,3-disubstituted benzimidazolium halides in DMSO. All the complexes have been characterized by using ${ }^{1} \mathrm{H}$ NMR, ${ }^{13} \mathrm{C}$ NMR, FTIR spectroscopy and elemental analysis techniques. The molecular and crystal structure of one of the complexes is confirmed by using single-crystal X-ray diffraction. These complexes have been examined as the catalyst in the direct arylation reaction with 2-n-butylfuran and 2-n-butylthiophene and have demonstrated excellent activity in this reaction.
\end{abstract}

Keywords. Bis(NHC)Pd(II) complex; butylfuran; butylthiophene; direct arylation; $N$-coordinate$\mathrm{Pd}(\mathrm{II})(\mathrm{NHC})$ complexes; $N$-heterocyclic carbene.

\section{Introduction}

The $N$-Heterocyclic carbenes (NHCs) were first reported by the independent works of Öfele and Wanzlick at the beginning of the $1960 \mathrm{~s},{ }^{1}$ and after a long time, in 1991 NHCs were reported as stable compounds that could be isolated by Arduengo et $a .^{2}$ NHCs are very versatile ligands in catalysis and organometallic chemistry ${ }^{3-6}$ which can be readily synthesized by the deprotonation of 1,3-diazonium salts. $^{7,8}$ They have tremendous potentials in organic synthesis and catalysis ${ }^{9-11}$ because of their extremely strong $\sigma$-donor and weak $\pi$-acceptor properties. ${ }^{12,13}$ Especially in the last decade, NHCs have become increasingly popular as they are suitable ligands for the synthesis of coordination compounds. Furthermore, organometallic chemists have been interested in NHCs due to their stability to air and moisture and capability of complexing with transition metals for half a century.

The palladium complexes containing NHC ligands that are easily tunable as sterically and electronically have thermal and oxidative stability and they are long-lived active catalysts. ${ }^{14,15}$ The efficient applications of Pd-NHC complexes have been published in the field of organometallic chemistry and catalysts for many years. ${ }^{16-21}$ Also, medical applications of NHC precursors $^{22-27}$ and Pd-NHC complexes ${ }^{28}$ have been examined.

Two different products can be obtained in the synthesis of bis(NHC)Pd(II) complexes. In particular, it is known that cis and trans isomeric products form depending on the experimental conditions. ${ }^{29-31}$ Recently, unusually, Han et al., performed a synthesis of a new type of bis(NHC)Pd(II) complexes from 1,3disubstituted NHC precursor containing bulky substituents in DMSO. ${ }^{32}$ This complex contains both the NHC (carbene) ligand and the N-bound (NHC precursor) ligand. Also, Landaeta et al., used different solvents for the synthesis of bis(NHC)Pd(II) complexes and obtained significant results. In that study, when the DMSO was used as the solvent, a balance is observed between the carbene ligand and $\mathrm{N}$-bound carbene precursor ligand as the result of the kinetic control. ${ }^{33}$

*For correspondence 
The palladium-based metal-catalyzed direct arylation reaction that has been used is quite common because of its high activity, selectivity, efficiency, and versatility. Various catalysts using in this reaction have been developed for environment-friendly syntheses. Numerous research groups have used the NHC-Pd metal catalysts in the formation of a C-C bond. Recently, the Pdbased NHC complexes have been applied in organic chemistry for important $\mathrm{C}-\mathrm{C}$ bond formations such as the Suzuki, ${ }^{34}$ Heck, ${ }^{34}$ Negishi, ${ }^{35}$ Stille, ${ }^{36}$ Hiyama coupling, ${ }^{37}$ Sonogashira coupling, ${ }^{38}$ Kumada coupling ${ }^{39}$ and Buchwald-Hartwig amination ${ }^{40}$ reactions.

In our last studies, we have published bis(NHC)Pd(II) complexes that are effective catalysts for direct arylation reactions. ${ }^{41-43}$ In this study, we have investigated the synthesis and characterization of the 2-hydroxyethyl substituted $\mathrm{N}$-coordinate-Pd(II)(NHC) and bis(NHC)Pd(II) complexes, and examined their catalytic activities in the direct arylation reactions. Also, we have found that the catalytic activities of these complexes are more efficient and stable catalysts for the direct arylation reactions of 2- $n$-butylfuran and 2-n-butylthiophene with aryl chloride or aryl bromide.

\section{Experimental}

All synthesis including 2-hydroxyethyl substituted $\mathrm{N}$-coordinate-Pd(II)(NHC) complexes $\mathbf{1 a - b}$ and bis(NHC)Pd(II) complexes 2a-g were prepared in the air using standard Schlenk techniques. The solvents and all other reagents were commercially available and used without further purification. Melting points were identified in glass capillaries under air with an Electrothermal-9200 melting point apparatus. FT-IR spectra were saved in the range $400-4000 \mathrm{~cm}^{-1}$ on Perkin Elmer Spectrum 100 FT-IR spectrometer. Proton $\left({ }^{1} \mathrm{H}\right)$ and Carbon $\left({ }^{13} \mathrm{C}\right)$ NMR spectra were recorded using either a Bruker AS 400 Merkur spectrometer operating at $400 \mathrm{MHz}$ $\left({ }^{1} \mathrm{H}\right), 100 \mathrm{MHz}\left({ }^{13} \mathrm{C}\right)$ in $\mathrm{CDCl}_{3}$ with tetramethylsilane as an internal reference. All reactions were observed on an Agilent 6890 N GC system by GC-FID with an HP-5 column of $30 \mathrm{~m}$ length, $0,32 \mathrm{~mm}$ diameter and $0,25 \mu \mathrm{m}$ film thickness. Elemental analyses were performed by İnönü University Scientific and Technological Research Center (Malatya, TURKEY).

$\mathrm{X}$-ray single-crystal diffraction data for complex $\mathbf{1 b}$ was collected at room temperature on a Rigaku-Oxford Xcalibur diffractometer with an EOS-CCD detector using graphitemonochromated $\mathrm{MoK} \alpha$ radiation $(\lambda=0.71073 \AA)$ with CrysAlis $^{\text {Pro }}$ software. $^{44}$ Data reduction and analytical absorption correction were performed by CrysAlis ${ }^{\text {Pro }}$ program. ${ }^{45}$ Utilizing Olex2, ${ }^{46}$ structure was solved using the Intrinsic Phasing method with SHELXT ${ }^{47}$ and refined by full-matrix least-squares on $F^{2}$ in SHELXL. ${ }^{48}$ Anisotropic thermal parameters were applied to all non-hydrogen atoms. All hydrogen atoms were placed using standard geometric models and with their thermal parameters riding on those of their parent atoms $(\mathrm{C}-\mathrm{H}=0.93,0.96$ and $0.97 \AA$, O-H = $0.82 \AA$ ). Some positional disorders were observed for hydroxyethyl groups in the structure, and to ensure satisfactory refinement of these disordered hydroxyethyl groups, constraint and restraint instructions such as EADP, DFIX, SIMU and RIGU were applied. A summary of crystal data, experimental details, and refinement results for the complex $\mathbf{1 b}$ are given in Table 1.

\subsection{Synthesis}

2.1a Synthesis of dichloro[1-(2-hydroxyethyl)-3methylbenzimidazol-2-ylidene)]-[1-(2-hydroxyethyl) benzimidazole]palladium(II), la: 1-(2-hydroxyethyl)3-methylbenzimidazolium chloride $(106 \mathrm{mg}$. $0.50 \mathrm{mmol})$ and Palladium(II)acetate $(56 \mathrm{mg}, 0.25 \mathrm{mmol})$ in dimethyl sulfoxide $(4 \mathrm{~mL})$ were stirred for $4 \mathrm{~h}$ at room temperature, 4 $\mathrm{h}$ at $50{ }^{\circ} \mathrm{C}, 4 \mathrm{~h}$ at $80{ }^{\circ} \mathrm{C}, 10 \mathrm{~h}$ at $100{ }^{\circ} \mathrm{C}$ and $2 \mathrm{~h}$ at $120{ }^{\circ} \mathrm{C}$. The excess of the solvent was removed by evaporation under vacuum. The dichloromethane was added to the residue. Then the residue was passed through a silica gel column ( $1 \mathrm{~cm}$ thick) by using dichloromethane solvent. The dichloromethane was evaporated under vacuum to allow the product as a white or light yellow solid. The crude product was recrystallized from dichloromethane/diethyl ether (1:3) at room temperature. Yield: 62\% (86 mg). M.p. 236-237 ${ }^{\circ} \mathrm{C} ; v_{(\mathrm{CN})(\text { for carbene) }}: 1400 \mathrm{~cm}^{-1} ; v_{(\mathrm{CN})}$ :(carbene precursor) 1517 $\mathrm{cm}^{-1} ; \quad v_{(\mathrm{O}-\mathrm{H})}$ : $3412 \mathrm{~cm}^{-1}$. Anal. Calc. for $\mathrm{C}_{19} \mathrm{H}_{22} \mathrm{Cl}_{2} \mathrm{~N}_{4} \mathrm{O}_{2}$ Pd: C: 44.25; H: 4.30; N: 10.86. Found: C: 44.22; H: 4.32; N: 10.85. ${ }^{1} \mathrm{H}$ NMR (400 MHz, $\left.\mathrm{CDCI}_{3}\right) ; \delta 1.63$ and $4.41\left(\mathrm{~s}, 2 \mathrm{H},-\mathrm{NCH}_{2} \mathrm{CH}_{2} \mathrm{OH}\right) ; 3.84\left(\mathrm{~s}, 3 \mathrm{H},-\mathrm{NCH}_{3}\right) ; 4.50$ $\left(\mathrm{m}, 4 \mathrm{H},-\mathrm{NCH}_{2} \mathrm{CH}_{2} \mathrm{OH}\right) ; 5.10(\mathrm{t}, 4 \mathrm{H}, J=6 \mathrm{~Hz}-$ $\left.\mathrm{NCH}_{2} \mathrm{CH}_{2} \mathrm{OH}\right) ; 7.26-8.33(\mathrm{~m}, 8 \mathrm{H}, \mathrm{Ar}-H) ; 8.50(\mathrm{~d}, 1 \mathrm{H}, J=$ $7.0 \mathrm{~Hz}, 2-\mathrm{CH}) .{ }^{13} \mathrm{C} \mathrm{NMR}\left(100 \mathrm{MHz}, \mathrm{CDCI}_{3}\right) ; \delta 31.6$ and 34.9 $\left(-\mathrm{NCH}_{2} \mathrm{CH}_{2} \mathrm{OH}\right) ; 50.6\left(-\mathrm{NCH}_{3}\right) ; 61.4$ and $61.6\left(-\mathrm{NCH}_{2}\right.$ $\left.\mathrm{CH}_{2} \mathrm{OH}\right)$; 109.8-110.1-110.4-110.6-120.7-123.4-123.5123.8-124.2-133.6-134.8, 135.0 and 140.4 (Ar-C); 144.3. (2-CH). 164.4 (2-C-Pd).

2.1b Synthesis of dibromo[1-(2-hydroxyethyl)-3ethylbenzimidazol-2-ylidene)]-[1-(2-hydroxyethyl)benzimidazole]palladium(II), $l b$ : This compound was prepared with the same procedure as that for 1a. But the complex $\mathbf{1 b}$ was prepared by using 1-ethyl-3-(2-hydroxyethyl) benzimidazolium bromide $(136 \mathrm{mg} .0 .50 \mathrm{mmol})$ instead of 1-(2-hydroxyethyl)-3-methylbenzimidazolium chloride. Yield: $67 \%(117 \mathrm{mg})$. M.p.: $176-177{ }^{\circ} \mathrm{C} ; v_{(\mathrm{CN})(\text { for carbene): }}$ : $1416 \mathrm{~cm}^{-1} ; v_{(\mathrm{CN})}$ :(carbene precursor) $1517 \mathrm{~cm}^{-1} ; v_{(\mathrm{O}-\mathrm{H})}: 3404$ $\mathrm{cm}^{-1}$. Anal. Calc. for $\mathrm{C}_{20} \mathrm{H}_{24} \mathrm{Br}_{2} \mathrm{~N}_{4} \mathrm{O}_{2} \mathrm{Pd}$ : C: $38.83 ; \mathrm{H}$ : 3.91 ; $\mathrm{N}: 9.06$. Found: C: 38.87 ; H: 3.88; N: 9.03. ${ }^{1} \mathrm{H}$ NMR (400 $\left.\mathrm{MHz}, \mathrm{CDCl}_{3}\right) ; \delta 1.78\left(\mathrm{t}, 3 \mathrm{H}, J=6 \mathrm{~Hz}-\mathrm{NCH}_{2} \mathrm{CH}_{3}\right) ; 1.66$ and $2.59\left(\mathrm{~s}, 2 \mathrm{H},-\mathrm{NCH}_{2} \mathrm{CH}_{2} \mathrm{OH}\right) ; 4.24\left(\mathrm{q}, 2 \mathrm{H},-\mathrm{NCH}_{2} \mathrm{CH}_{3}\right)$; 4.50 and $4.92\left(\mathrm{t}, 4 \mathrm{H}, J=4\right.$ and $\left.4 \mathrm{~Hz},-\mathrm{NCH}_{2} \mathrm{CH}_{2} \mathrm{OH}\right) ; 4.57$ and $4.99\left(\mathrm{t}, \mathrm{m}, 4 \mathrm{H}, \mathrm{J}=4 \mathrm{~Hz}-\mathrm{NCH}_{2} \mathrm{CH}_{2} \mathrm{OH}\right) ; 7.26-8.52(\mathrm{~m}$, 
Table 1. Crystal data and experimental details for the complex $\mathbf{1 b}$.

\begin{tabular}{ll}
\hline Empirical Formula & $\mathrm{C}_{20} \mathrm{H}_{24} \mathrm{Br}_{2} \mathrm{~N}_{4} \mathrm{O}_{2} \mathrm{Pd}$ \\
Formula Weight & 618.65 \\
Temperature $(\mathrm{K})$ & $293(2)$ \\
Crystal System, space group & Triclinic, $P-1$ \\
$a, b, c(\AA)$ & $8.6912(5), 8.7380(5), 14.9619(8)$ \\
$\alpha, \beta, \gamma\left({ }^{\circ}\right)$ & $79.057(5), 85.805(4), 81.429(5)$ \\
$V\left(\AA^{3}\right)$ & $1101.96(11) 81.429(5)$ \\
$Z$ & 2 \\
Density (calculated) $\left(\mathrm{g} / \mathrm{cm}^{3}\right)$ & 1.864 \\
Absorption coefficient $\left(\mu, \mathrm{mm}^{-1}\right)$ & 4.492 \\
$F(000)$ & 608 \\
Crystal size $\left(\mathrm{mm}^{3}\right)$ & $0.364 \times 0.189 \times 0.151$ \\
Radiation & $\mathrm{MoK} \alpha(\lambda=0.71073)$ \\
$2 \theta$ range for data collection $\left(^{\circ}\right)$ & $6.264-51.362$ \\
Index ranges & $-10 \leq \mathrm{h} \leq 8,-10 \leq \mathrm{k} \leq 9,-13 \leq 1 \leq 18$ \\
Reflections collected & 5705 \\
Independent reflections & $4147\left[\mathrm{R}_{\mathrm{int}}=0.023, \mathrm{R}_{\text {sigma }}=0.063\right]$ \\
Restraints/Parameters & $28 / 253$ \\
Goodness-of-fit on $F^{2}$ & 1.025 \\
Final $R$ indices $[I \geq 2 \sigma(I)]$ & $R_{1}=0.053, w R_{2}=0.116$ \\
$R$ indices & $R_{1}=0.092, w R_{2}=0.136$ \\
Largest diff. peak/hole $\left(\mathrm{e} \AA^{-3}\right)$ & $1.11 /-0.82$ \\
\hline
\end{tabular}

$8 \mathrm{H}, \mathrm{Ar}-H) ; 9.06$ and $9.10(\mathrm{dd}, 1 \mathrm{H}, J=6.4$ and $6.4 \mathrm{~Hz}$, 2-CH). ${ }^{13} \mathrm{C}$ NMR $\left(100 \mathrm{MHz}, \mathrm{CDCl}_{3}\right) ; \delta 14.4$ and 14.9 $\left(-\mathrm{NCH}_{2} \mathrm{CH}_{3}\right) ; 40.8$ and $43.9\left(-\mathrm{NCH}_{2} \mathrm{CH}_{2} \mathrm{OH}\right) ; 50.8$ $\left(-\mathrm{NCH}_{2} \mathrm{CH}_{3}\right) ; 61.2$ and $65.8\left(-\mathrm{NCH}_{2} \mathrm{CH}_{2} \mathrm{OH}\right) ; 110.0-$ 110.1-110.3-110.4-110.8-110.9-123.1-123.2-124.6-124.7132.8-134.0-134.3-135.6-138.0, 138.1 and $140.8(\mathrm{Ar}-\mathrm{C})$; $143.8(2-\mathrm{CH}) ; 161.5$ and 163.9. (2-C-Pd).

2.1c Synthesis of cis/trans-dibromobis[1-(2hydroxyethyl)-3-isopropylbenzimidazol-2-ylidene]palla$\operatorname{dium}(I I), 2 a$ : This compound was prepared with the same procedure as that for 1a. But the complex 2a was prepared by using 1-(2-hydroxyethyl)-3-isopropylbenzimidazolium bromide $(143 \mathrm{mg}$. $0.50 \mathrm{mmol})$ instead of 1-(2hydroxyethyl)-3-methylbenzimidazolium chloride. Yield: 79\% (133 mg). M.p.: $169-170{ }^{\circ} \mathrm{C} ; v_{(\mathrm{CN})}: 1403 \mathrm{~cm}^{-1}$; $v_{(\mathrm{O}-\mathrm{H})}: 3381 \mathrm{~cm}^{-1}$. Anal. Calc. for $\mathrm{C}_{24} \mathrm{H}_{32} \mathrm{Br}_{2} \mathrm{~N}_{4} \mathrm{O}_{2} \mathrm{Pd}$ : C: 42.72; H: 4.78; N: 8.30. Found: C: 42.68; H: 4.80; N: 8.32. ${ }^{1} \mathrm{H}$ NMR $\left(400 \mathrm{MHz}, \mathrm{CDCl}_{3}\right) ; \delta 1.65$ and $2.61(\mathrm{~s}, 2 \mathrm{H},-$ $\mathrm{NCH}_{2} \mathrm{CH}_{2} \mathrm{OH}$ ); 1.80 and $1.82(\mathrm{~d}, \mathrm{~d}, 12 \mathrm{H}, J=4$ and $4 \mathrm{~Hz}-$ $\left.\mathrm{NCH}\left(\mathrm{CH}_{3}\right)_{2}\right) ; 4.33$ and $4.43(\mathrm{t}, 4 \mathrm{H}, J=6$ and $6 \mathrm{~Hz}-$ $\left.\mathrm{NCH}_{2} \mathrm{CH}_{2} \mathrm{OH}\right) ; 4.84$ and $4.93\left(\mathrm{~m}, 4 \mathrm{H},-\mathrm{NCH}_{2} \mathrm{CH}_{2} \mathrm{OH}\right)$; 5.92 and $6.07\left(\mathrm{~m}, 1 \mathrm{H}, \mathrm{Hz}-\mathrm{NCH}\left(\mathrm{CH}_{3}\right)_{2}\right) ; 7.26-7.60(\mathrm{~m}, 8 \mathrm{H}$, Ar- $H) .{ }^{13} \mathrm{C}$ NMR $\left(100 \mathrm{MHz}, \mathrm{CDCl}_{3}\right) ; \delta 20.4$ ve $20.6(-$ $\left.\mathrm{NCH}\left(\mathrm{CH}_{3}\right)_{2}\right) ; 50.8$ and $51.4\left(-\mathrm{NCH}\left(\mathrm{CH}_{3}\right)_{2}\right) ; 54.5$ and 55.0 $\left(-\mathrm{NCH}_{2} \mathrm{CH}_{2} \mathrm{OH}\right) ; \quad 60.8$ and $61.2 \quad\left(-\mathrm{NCH}_{2} \mathrm{CH}_{2} \mathrm{OH}\right)$; 110.3-110.6-110.9-111.0-112.5-112.6-122.6-122.8-122.7$122.8-132.5-132.6-132.7-135.1-135.7-136.3$ and 136.8 (Ar-C); 178.9 and 180.9 (2-C-Pd).

2.1d Synthesis of cis/trans-dichlorobis[1-benzyl-3(2-hydroxyethyl)benzimidazol-2-ylidene]palladium(II),

$2 b$ : This compound was prepared with the same procedure as that for 1a. But the complex $\mathbf{2 b}$ was prepared by using 1-benzyl-3-(2-hydroxyethyl)benzimidazolium chloride $(144 \mathrm{mg}$. $0.50 \mathrm{mmol})$ instead of 1-(2-hydroxyethyl)-3-methylbenzimidazolium chloride. Yield: $75 \%$ (128 mg). M.p. $156-157{ }^{\circ} \mathrm{C} ; v_{(\mathrm{CN})}: 1411$ $\mathrm{cm}^{-1} ; \quad v_{(\mathrm{O}-\mathrm{H})}: 3423 \mathrm{~cm}^{-1}$. Anal. Calc. for $\mathrm{C}_{32} \mathrm{H}_{32}$ $\mathrm{Cl}_{2} \mathrm{~N}_{4} \mathrm{O}_{2} \mathrm{Pd}$ : C: 56.36; $\mathrm{H}: 4.73$; N: 8.22. Found: C: 56.40; H: 4.72; N: 8.27. ${ }^{1} \mathrm{H}$ NMR $\left(400 \mathrm{MHz}, \mathrm{CDCI}_{3}\right) ; \delta 1.68$ and $2.60\left(\mathrm{~s}, 2 \mathrm{H},-\mathrm{NCH}_{2} \mathrm{CH}_{2} \mathrm{OH}\right) ; 3.86$ and $4.21(\mathrm{~m}, 4 \mathrm{H},-$ $\mathrm{NCH}_{2} \mathrm{CH}_{2} \mathrm{OH}$ ); 4.91 and 5.14 (s, $\left.4 \mathrm{H},-\mathrm{NCH}_{2} \mathrm{CH}_{2} \mathrm{OH}\right) ; 6.04$ and $6.34\left(\mathrm{~s}, 4 \mathrm{H},-\mathrm{NCH}_{2}\left(\mathrm{C}_{6} \mathrm{H}_{5}\right) ; 7.23-8.49(\mathrm{~m}, 18 \mathrm{H}, \mathrm{Ar}-\mathrm{H})\right.$. ${ }^{13} \mathrm{C} \quad \mathrm{NMR} \quad\left(100 \quad \mathrm{MHz}, \quad \mathrm{CDCI}_{3}\right) ; \quad \delta \quad 47.8$ and 48.3 $\left(-\mathrm{NCH}_{2} \mathrm{CH}_{2} \mathrm{OH}\right) ; 52.2$ and $53.1\left(-\mathrm{NCH}_{2}\left(\mathrm{C}_{6} \mathrm{H}_{5}\right) ; 60.7\right.$ and $61.4\left(-\mathrm{NCH}_{2} \mathrm{CH}_{2} \mathrm{OH}\right) ; 110.5-110.7-111.3-111.5-123.1-$ 123.2-123.4-127.4-127.6-127.7-127.8-128.1-128.7-128.8128.9-129.2-133.0-134.0-134.3-134.4-134.6-135.3-135.4 and 135.7. (Ar-C); 181.3 and 182.0 (2-C-Pd).

2.1e Synthesis of cis/trans-dichlorobis[1-(2-hydroxyethyl)-3-(2-methylbenzyl)benzimidazol-2-ylidene]palla $\operatorname{dium}(I I), 2 c$ : This compound was prepared with the same procedure as that for 1a. But the complex $\mathbf{2 c}$ was prepared by using 1-(2-hydroxyethyl)-3-(2-methylbenzyl)benzimidazolium chloride $(151 \mathrm{mg}$. $0.50 \mathrm{mmol})$ instead of 1-(2hydroxyethyl)-3-methylbenzimidazolium chloride. Yield: 69\% (122 mg). M.p.: $227-228{ }^{\circ} \mathrm{C} ; v_{(\mathrm{CN})}: 1401 \mathrm{~cm}^{-1}$; $v_{(\mathrm{O}-}$ H) $3404 \mathrm{~cm}^{-1}$. Anal. Calc. for $\mathrm{C}_{34} \mathrm{H}_{36} \mathrm{Cl}_{2} \mathrm{~N}_{4} \mathrm{O}_{2} \mathrm{Pd}: \mathrm{C}: 57.52$; $\mathrm{H}: 5.11 ; \mathrm{N}: 7.89$. Found: C: $57.50 ; \mathrm{H}: 5.08 ; \mathrm{N}: 7.90 .{ }^{1} \mathrm{H}$ NMR $\left(400 \mathrm{MHz}, \mathrm{CDCI}_{3}\right) ; \delta 1.77$ and $2.60(\mathrm{~s}, 2 \mathrm{H},-$ $\left.\mathrm{NCH}_{2} \mathrm{CH}_{2} \mathrm{OH}\right) ; 2.22$ and $2.32\left(\mathrm{~s}, 6 \mathrm{H},-\mathrm{NCH}_{2}\left(\mathrm{C}_{6} \mathrm{H}_{4}\right) \mathrm{CH}_{3}\right)$; 3.73 and $3.87\left(\mathrm{~m}, 4 \mathrm{H},-\mathrm{NCH}_{2} \mathrm{CH}_{2} \mathrm{OH}\right) ; 4.23$ and $4.54(\mathrm{~m}$, $\left.4 \mathrm{H}, \quad-\mathrm{NCH}_{2} \mathrm{CH}_{2} \mathrm{OH}\right) ; \quad 5.78$ and $5.91(\mathrm{~s}, \quad 4 \mathrm{H}, \quad-$ $\mathrm{NCH}_{2} \mathrm{C}_{6} \mathrm{H}_{4}\left(\mathrm{CH}_{3}\right)$ ); 6.76-7.64 (m, $\left.16 \mathrm{H}, \mathrm{Ar}-H\right) .{ }^{13} \mathrm{C}$ NMR 
$\left(100 \mathrm{MHz}, \mathrm{CDCI}_{3}\right) ; \delta 19.5$ and $19.6\left(-\mathrm{NCH}_{2}\left(\mathrm{C}_{6} \mathrm{H}_{4}\right) \mathrm{CH}_{3}\right)$; 50.3 and $50.6\left(-\mathrm{NCH}_{2} \mathrm{CH}_{2} \mathrm{OH}\right) ; 52.0\left(-\mathrm{NCH}_{2}\left(\mathrm{C}_{6} \mathrm{H}_{5}\right) ; 60.1\right.$ and $60.7 \quad\left(-\mathrm{NCH}_{2} \mathrm{CH}_{2} \mathrm{OH}\right) ; 111.0-112.5-112.9-113.0$ 121.9-122.5-122.7-124.4-124.8-126.6-126.7-126.9-127.1128.2-128.3-128.7-130.9-131.0-131.3-134.1-134.2-134.8136.2-136.9 and 137.1. (Ar-C); 189.8 and 190.0 (2-C-Pd).

2.1f Synthesis of cis/trans-dichlorobis[1-(2-hydroxyethyl)-3-(3-methylbenzyl)benzimidazol-2-ylidene]palla$\operatorname{dium}(I I), 2 d$ : This compound was prepared with the same procedure as that for 1a. But the complex 2d was prepared by using 1-(2-hydroxyethyl)-3-(3-methylbenzyl)benzimidazolium chloride $(151 \mathrm{mg}$. $0.50 \mathrm{mmol})$ instead of 1-(2-hydroxyethyl)-3-methylbenzimidazolium chloride. Yield: $74 \%$ (131 mg). M.p. $175-176{ }^{\circ} \mathrm{C} ; v_{(\mathrm{CN})}$ : 1410 $\mathrm{cm}^{-1} ; \quad v_{(\mathrm{O}-\mathrm{H})}: 3404 \mathrm{~cm}^{-1}$. Anal. Calc. for $\mathrm{C}_{34} \mathrm{H}_{36} \mathrm{Cl}_{2} \mathrm{~N}_{4} \mathrm{O}_{2} \mathrm{Pd}$ : C: $57.52 ; \mathrm{H}: 5.11 ; \mathrm{N}: 7.89$. Found: C: 57.56; H: 5.14; N: 7.92. ${ }^{1} \mathrm{H}$ NMR (400 MHz, $\left.\mathrm{CDCI}_{3}\right) ; \delta$ 1.65 and 2.60 (s, $\left.2 \mathrm{H},-\mathrm{NCH}_{2} \mathrm{CH}_{2} \mathrm{OH}\right) ; 2.55$ and 2.59 (s, $6 \mathrm{H}$, $\left.-\mathrm{NCH}_{2}\left(\mathrm{C}_{6} \mathrm{H}_{4}\right) \mathrm{CH}_{3}\right) ; 3.47$ and $3.82\left(\mathrm{~m}, 4 \mathrm{H},-\mathrm{NCH}_{2} \mathrm{CH}_{2} \mathrm{OH}\right)$; 5.17 and $5.29\left(\mathrm{~s}, 4 \mathrm{H},-\mathrm{NCH}_{2} \mathrm{CH}_{2} \mathrm{OH}\right) ; 5.83$ and $6.32(\mathrm{~s}, 4 \mathrm{H}$, $\left.-\mathrm{NCH}_{2} \mathrm{C}_{6} \mathrm{H}_{4}\left(\mathrm{CH}_{3}\right)\right)$; 6.93-7.66 (m, $\left.16 \mathrm{H}, \mathrm{Ar}-\mathrm{H}\right) .{ }^{13} \mathrm{C} \mathrm{NMR}$ $\left(100 \mathrm{MHz}, \mathrm{CDCI}_{3}\right) ; \delta 19.8$ and $22.3\left(-\mathrm{NCH}_{2}\left(\mathrm{C}_{6} \mathrm{H}_{4}\right) \mathrm{CH}_{3}\right)$; 31.6 and $34.1\left(-\mathrm{NCH}_{2} \mathrm{CH}_{2} \mathrm{OH}\right) ; 47.8$ and $50.4\left(-\mathrm{NCH}_{2}\right.$ $\left(\mathrm{C}_{6} \mathrm{H}_{5}\right)$; 60.6 and $61.3\left(-\mathrm{NCH}_{2} \mathrm{CH}_{2} \mathrm{OH}\right) ; 111.3-112.5-$ 123.4-123.5-126.6-126.9-127.8-127.9-128.1-128.3-128.8130.4-130.7-133.1-133.3-134.4-134.6-135.1 and 135.5. (Ar-C); 180.3 and 180.7 (2-C-Pd).

2.1g Synthesis of cis/trans-dichlorobis[1-(2-hydroxyethyl)-3-(4-methylbenzyl)benzimidazol-2-ylidene]palla$\operatorname{dium}(I I), 2 e$ : This compound was prepared with the same procedure as that for 1a. But the complex 2e was prepared by using 1-(2-hydroxyethyl)-3-(4-methylbenzyl)benzimidazolium chloride $(151 \mathrm{mg}$. $0.50 \mathrm{mmol})$ instead of 1-(2-hydroxyethyl)-3-methylbenzimidazolium chloride. Yield: $70 \%$ (124 mg). M.p. $224-225{ }^{\circ} \mathrm{C} ; v_{(\mathrm{CN})}$ : 1407 $\mathrm{cm}^{-1} ; \quad v_{(\mathrm{O}-\mathrm{H})}: 3431 \mathrm{~cm}^{-1}$. Anal. Calc. for $\mathrm{C}_{34} \mathrm{H}_{36} \mathrm{Cl}_{2} \mathrm{~N}_{4} \mathrm{O}_{2} \mathrm{Pd}$ : C: $57.52 ; \mathrm{H}: 5.11 ; \mathrm{N}: 7.89$. Found: C: 57.51; H: 5.13; N: 7.86. ${ }^{1} \mathrm{H}$ NMR $\left(400 \mathrm{MHz}, \mathrm{CDCI}_{3}\right) ; \delta$ 1.65 and 2.60 (s, $\left.2 \mathrm{H},-\mathrm{NCH}_{2} \mathrm{CH}_{2} \mathrm{OH}\right) ; 2.27$ and $2.34(\mathrm{~s}, 6 \mathrm{H}$, $\left.-\mathrm{NCH}_{2}\left(\mathrm{C}_{6} \mathrm{H}_{4}\right) \mathrm{CH}_{3}\right) ; 4.22$ and $4.32\left(\mathrm{~m}, 4 \mathrm{H},-\mathrm{NCH}_{2} \mathrm{CH}_{2} \mathrm{OH}\right)$; 4.93 and $5.14\left(\mathrm{~s}, 4 \mathrm{H},-\mathrm{NCH}_{2} \mathrm{CH}_{2} \mathrm{OH}\right) ; 5.92$ and $6.18(\mathrm{~s}, 4 \mathrm{H}$, $\left.-\mathrm{NCH}_{2} \mathrm{C}_{6} \mathrm{H}_{4}\left(\mathrm{CH}_{3}\right)\right) ; 7.03-7.55(\mathrm{~m}, 16 \mathrm{H}, \mathrm{Ar}-\mathrm{H}) .{ }^{13} \mathrm{C}$ NMR $\left(100 \mathrm{MHz}, \mathrm{CDCI}_{3}\right) ; \delta 21.1$ and $21.2\left(-\mathrm{NCH}_{2}\left(\mathrm{C}_{6} \mathrm{H}_{4}\right) \mathrm{CH}_{3}\right)$; 50.3 and $50.4\left(-\mathrm{NCH}_{2} \mathrm{CH}_{2} \mathrm{OH}\right) ; 52.2$ and $52.4\left(-\mathrm{NCH}_{2}\right.$ $\left(\mathrm{C}_{6} \mathrm{H}_{5}\right) ; 61.5$ and $61.7\left(-\mathrm{NCH}_{2} \mathrm{CH}_{2} \mathrm{OH}\right) ; 110.3-110.5-$ 120.7-111.5-111.6-111.9-123.1-123.3-123.7-127.3-127.7129.4-129.6-132.4-132.5-134.3-134.4-134.6-134.9-137.6 and 137.8. (Ar-C); 181.0 and 181.2 (2-C-Pd).

2.1h Synthesis of cis/trans-dichlorobis[1-(2-hydroxyethyl)-3-(2,4,6-trimethylbenzyl)benzimidazol-2-ylidene] palladium(II), $2 f$ : This compound was prepared with the same procedure as that for 1a. But the complex $2 \mathbf{f}$ was prepared by using 1-(2-hydroxyethyl)-3-(2,4,6- trimethylbenzyl)benzimidazolium chloride (165 mg. 0.50 mmol) instead of 1-(2-hydroxyethyl)-3-methylbenzimidazolium chloride. Yield: 76\% (146 mg). M.p.: 236-238 ${ }^{\circ} \mathrm{C} ; v_{(\mathrm{CN})}: 1399 \mathrm{~cm}^{-1} ; v_{(\mathrm{O}-\mathrm{H})}: 3423 \mathrm{~cm}^{-1}$. Anal. Calc. for $\mathrm{C}_{38} \mathrm{H}_{44} \mathrm{Cl}_{2} \mathrm{~N}_{4} \mathrm{O}_{2} \mathrm{Pd}$ : C: $59.57 \mathrm{H}: 5.79$; N: 7.31. Found: C: 59.63; H: 5.82; N: 7.36. ${ }^{1} \mathrm{H}$ NMR (400 MHz, $\left.\mathrm{CDCI}_{3}\right) ; \delta$ 1.76 and 2.59 (s, $\left.2 \mathrm{H},-\mathrm{NCH}_{2} \mathrm{CH}_{2} \mathrm{OH}\right) ; 2.25-2.29$ and 2.32-2.39 (s, 9H, $\left.-\mathrm{NCH}_{2} \mathrm{C}_{6} \mathrm{H}_{2}\left(\mathrm{CH}_{3}\right)_{3}\right) ; 4.02$ and $4.28(\mathrm{~m}$, $4 \mathrm{H},-\mathrm{NCH}_{2} \mathrm{CH}_{2} \mathrm{OH}$ ); 5.10 and 5.18 (t, $4 \mathrm{H}, J=6$ and $6 \mathrm{~Hz}-$ $\left.\mathrm{NCH}_{2} \mathrm{CH}_{2} \mathrm{OH}\right) ; 5.29$ and $5.32\left(\mathrm{~s}, 4 \mathrm{H},-\mathrm{NCH}_{2} \mathrm{C}_{6} \mathrm{H}_{2}\left(\mathrm{CH}_{3}\right)_{3}\right)$; 6.33-7.39 (m, 12H, Ar- $H) .{ }^{13} \mathrm{C}$ NMR (100 MHz, $\left.\mathrm{CDCI}_{3}\right) ; \delta$ 20.9-21.0 and $22.3\left(-\mathrm{NCH}_{2} \mathrm{C}_{6} \mathrm{H}_{2}\left(\mathrm{CH}_{3}\right)_{3}\right) ; 30.4$ and 34.1 ($\left.\mathrm{NCH}_{2} \mathrm{CH}_{2} \mathrm{OH}\right) ; 49.6$ and $50.2\left(-\mathrm{NCH}_{2} \mathrm{C}_{6} \mathrm{H}_{4}\left(\mathrm{CH}_{3}\right)_{3}\right) ; 61.2$ and $61.5\left(-\mathrm{NCH}_{2} \mathrm{CH}_{2} \mathrm{OH}\right) ; 110.2-110.4-111.3-112.5-$ 111.9-122.8-123.0-123.3-123.7-127.5-128.0-128.1-128.3128.5-134.2-134.5-134.7-138.4 and 138.5. (Ar-C); 180.9 and 182.3 (2-C-Pd).

2.1i Synthesis of cis/trans-dichlorobis[1-(2-hydrox yethyl)-3-(2,3,4,5,6-pentamethylbenzyl)benzimidazol2-ylidene]palladium(II), 2g: This compound was prepared with the same procedure as that for 1a. But the complex $\mathbf{2 g}$ was prepared by using 1-(2-hydroxyethyl)-3(2,3,4,5,6-pentamethylbenzyl)benzimidazolium chloride (180 mg. $0.50 \mathrm{mmol}$ ) instead of 1-(2-hydroxyethyl)-3methylbenzimidazolium chloride. Yield: $71 \%(145 \mathrm{mg})$. M.p.: $245-246{ }^{\circ} \mathrm{C} ; v_{(\mathrm{CN})}: 1396 \mathrm{~cm}^{-1} ; v_{(\mathrm{O}-\mathrm{H})}: 3457 \mathrm{~cm}^{-1}$. Anal. Calc. for $\mathrm{C}_{42} \mathrm{H}_{52} \mathrm{Cl}_{2} \mathrm{~N}_{4} \mathrm{O}_{2} \mathrm{Pd}$ : C: 61.35; H: 6.37; N: 6.81. Found: C: 61.39 ; H: 6.40 ; N: $6.84 .{ }^{1} \mathrm{H}$ NMR (400 $\left.\mathrm{MHz}, \mathrm{CDCI}_{3}\right) ; \delta 1.67$ and $2.61\left(\mathrm{~s}, 2 \mathrm{H},-\mathrm{NCH}_{2} \mathrm{CH}_{2} \mathrm{OH}\right)$; 2.11-2.13-2.20-2.23 and 2.27 (s, 30H, $\left.-\mathrm{NCH}_{2} \mathrm{C}_{6}\left(\mathrm{CH}_{3}\right)_{5}\right)$; 3.75 and $4.44\left(\mathrm{~m}, 4 \mathrm{H},-\mathrm{NCH}_{2} \mathrm{CH}_{2} \mathrm{OH}\right) ; 5.10$ and $5.18(\mathrm{t}$, $4 \mathrm{H}, J=6$ and $\left.6 \mathrm{~Hz}-\mathrm{NCH}_{2} \mathrm{CH}_{2} \mathrm{OH}\right) ; 6.22$ and $6.32(\mathrm{~s}, 4 \mathrm{H},-$ $\left.\mathrm{NCH}_{2} \mathrm{C}_{6}\left(\mathrm{CH}_{3}\right)_{5}\right) ; 6.94-7.81(\mathrm{~m}, 8 \mathrm{H}, \mathrm{Ar}-H) .{ }^{13} \mathrm{C}$ NMR (100 $\left.\mathrm{MHz}, \mathrm{CDCI}_{3}\right) ; \delta$ 16.5-16.6-16.8-17.0-17.1 and 17.2 $\left(-\mathrm{NCH}_{2} \mathrm{C}_{6}\left(\mathrm{CH}_{3}\right)_{5}\right) ; 49.7$ and $50.0\left(-\mathrm{NCH}_{2} \mathrm{CH}_{2} \mathrm{OH}\right) ; 64.7$ and $64.8\left(-\mathrm{NCH}_{2} \mathrm{C}_{6}\left(\mathrm{CH}_{3}\right)_{5}\right) ; 61.0$ and $61.2\left(-\mathrm{NCH}_{2}\right.$ $\left.\mathrm{CH}_{2} \mathrm{OH}\right)$; $\quad 110.9-111.8-122.5-122.5-122.8-127.8-128.2-$ 132.5-132.7-132.9-133.3-133.4-133.7-135.0-135.1 and 135.4. (Ar-C); 181.8 and 181.9 (2-C-Pd).

$2.1 \mathrm{j}$ General method for direct arylation of 2-nbutylfuran and 2-n-butylthiophene with aryl halides: The derivatives of heteroaryl (2-n-butylfuran and 2- $n$-butylthiophene) $(2 \mathrm{mmol})$, the derivatives of aryl chloride/bromide (4-chloroacetophenone, 4-chloroanisole, 4-bromoacetophenone, 4-bromoanisole) (1 mmol), KOAc $(1 \mathrm{mmol})$ and the $N$-coordinate-Pd(II)(NHC) complexes 1ab or bis(NHC)Pd(II) complexes $\mathbf{2 a}-\mathbf{g}(0.3 \%$ mmol $)$ were dissolved in $N, N$-dimethylacetamide (DMAc) $(2 \mathrm{~mL})$ in a small Schlenk tube as described in the literature. ${ }^{42,43,52}$ The reaction mixture was stirred in an oil bath at $130{ }^{\circ} \mathrm{C}$ for 1 $\mathrm{h} / 16 \mathrm{~h}$. The solvent was removed under vacuum. The mixture was purified by using the column chromatography (silica gel 60-120 mesh) with ethylacetat $/ n$-hexane (1:5) as eluent to obtain the pure product. The purity of the 
<smiles>[R][Y]1c2ccccc2N(CCO)N1[Y]</smiles>
(1)

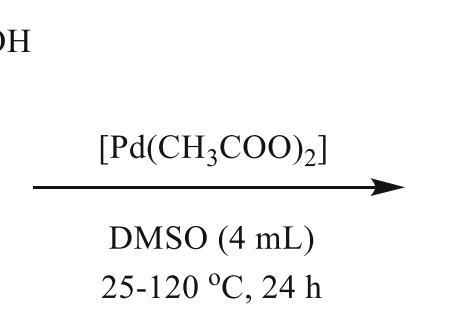

$25-120{ }^{\circ} \mathrm{C}, 24 \mathrm{~h}$<smiles></smiles>

1

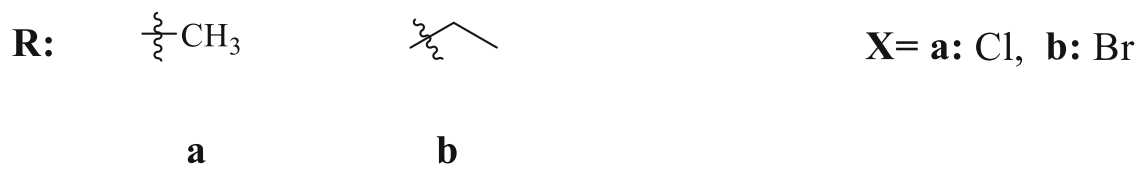

Scheme 1. Synthesis of 2-hydroxyethyl substituted $N$-coordinate-Pd(II)(NHC) complexes 1a-b.

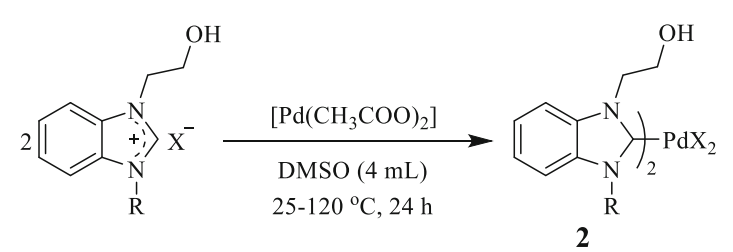

R:

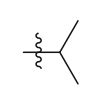

a

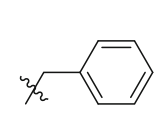

b

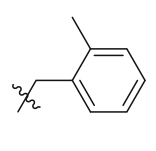

c

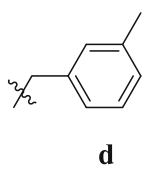

d

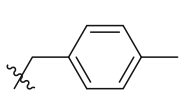

e

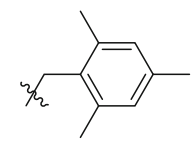

f

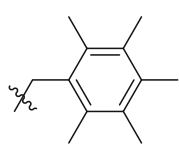

g
$\mathbf{X}=\mathbf{a}: \mathrm{Br}, \mathbf{b}-\mathbf{g}: \mathrm{Cl}$

Scheme 2. Synthesis of 2-hydroxyethyl substituted bis(NHC)Pd(II) complexes $\mathbf{2 a}-\mathbf{g}$.

compounds was checked by gas chromatography (GC). The conversions were calculated by taking into account the conversion of the aryl bromides to the products.

\section{Results and Discussion}

\subsection{Synthesis of $N$-coordinate-Pd(II)(NHC)} complexes (1a-b) and bis(NHC)Pd(II) Complexes (2a-g)

The 2-hydroxyethyl substituted $N$-coordinate$\mathrm{Pd}(\mathrm{II})(\mathrm{NHC})$ complexes $\mathbf{1 a}-\mathbf{b}$ and bis(NHC)Pd(II) complexes $\mathbf{2} \mathbf{a}-\mathbf{g}$ were synthesized from the reaction of NHC precursors and palladium acetate. The 2-hydroxyethyl substituted NHC precursors and palladium acetate $\left[\mathrm{Pd}\left(\mathrm{CH}_{3} \mathrm{COO}\right)_{2}\right]$ were used to obtain all the desired complexes that have been illustrated in Schemes 1 and 2. The $N$-coordinate-Pd(II)(NHC) complexes 1a-b and bis(NHC)Pd(II) complexes 2ag were prepared by mixing 1-alkyl(or aryl)-3-(2-hydroxyethyl)benzimidazolium salts with 0.5 equivalents palladium acetate $\left[\mathrm{Pd}\left(\mathrm{CH}_{3} \mathrm{COO}\right)_{2}\right]$ in dimethylsulfoxide $(4 \mathrm{~mL})$. The reaction mixture was stirred at 25-120 ${ }^{\circ} \mathrm{C}$ temperature for $24 \mathrm{~h}$. All the complexes $(\mathbf{1 a}-\mathbf{b}$ and 2a-g) were obtained as a yellow and white solid in $69 \%$ to $78 \%$ yield. The air and moisture stable complexes (1a-b and $\mathbf{2 a -}-\mathbf{g})$ are soluble both in polar solvents such as dimethylformamide, dimethylsulfoxide and in halogenated solvents such as dichloromethane and chloroform. The formations of the 2-hydroxyethyl substituted complexes (1a-b and $\mathbf{2 a - g})$ were confirmed by FT-IR, ${ }^{1} \mathrm{H}$ NMR and ${ }^{13} \mathrm{C}$ NMR spectroscopic methods and elemental analysis techniques. The conditions of this experiment indicated the formation of the unexpected novel $\mathrm{N}$-coordinate$\mathrm{Pd}(\mathrm{II})(\mathrm{NHC})$ complexes. ${ }^{32,33}$ In the ${ }^{1} \mathrm{H}$ NMR spectra, a characteristic proton peak at the 2-position (NCHN) of the 2-hydroxyethyl substituted N-coordinate$\mathrm{Pd}(\mathrm{II})(\mathrm{NHC})$ complexes 1a-b was detected, which appeared highly downfield shifted singleds $\delta 8.50$ and 9.06-9.10 ppm in the ${ }^{1} \mathrm{H}$ NMR spectra, respectively. In the ${ }^{13} \mathrm{C}$ NMR spectra, the $2-\mathrm{CH}$ resonances of the novel $\mathrm{N}$-coordinate-Pd(II)(NHC) complexes appeared highly downfield shifted at 144.3 and $143.8 \mathrm{ppm}$ for $\mathbf{1 a}-\mathbf{b}$, respectively. Also, the conditions of this experiment indicated the formation of the expected 


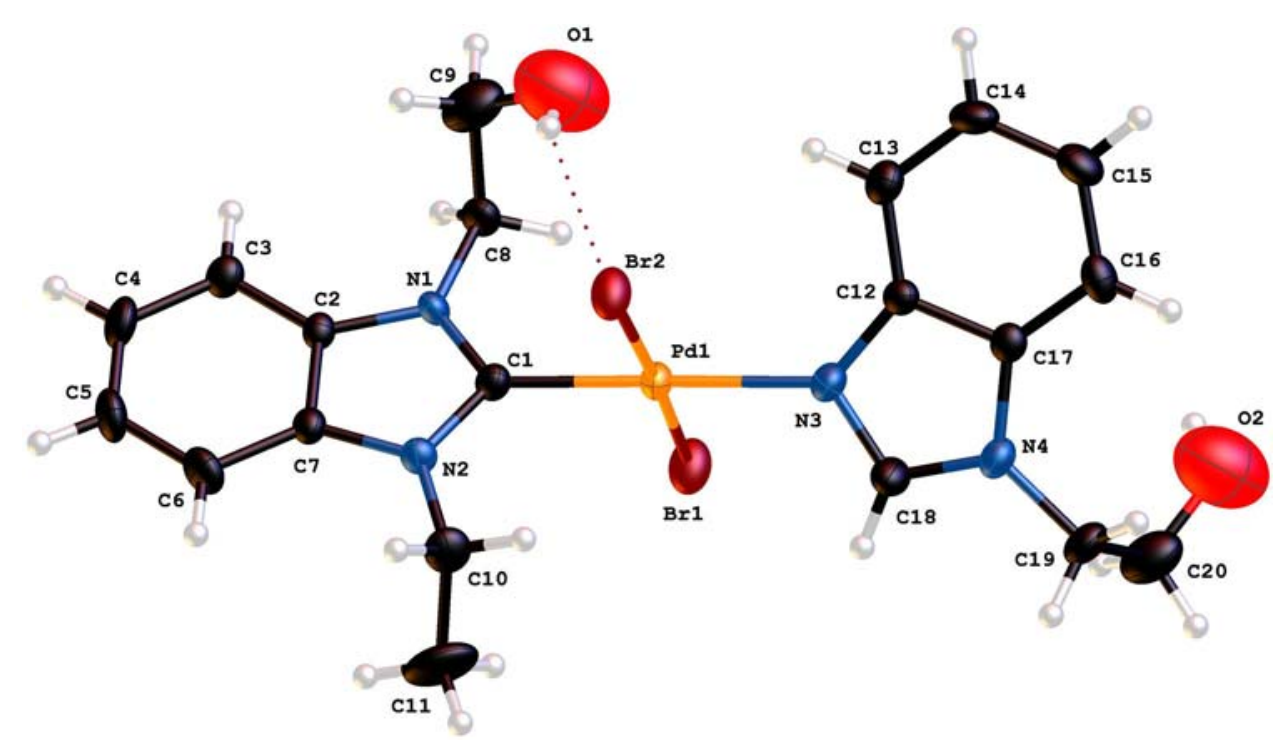

Figure 1. Molecular structure of complex $\mathbf{1 b}$ with ellipsoids drawn at $30 \%$ probability level. Selected bond lengths $(\AA)$ and angles $\left({ }^{\circ}\right)$ : Pd1-Br1 2.4260(11), Pd1-Br2 2.4426(11), Pd1-C1 1.959(7), Pd1-N3 2.080(6), O1-C9 1.398(9), O2-C20 1.386(8); Br1-Pd1-Br2 176.73(4), N3-Pd1-C1 177.9(3), Br1-Pd1-C1 91.0(2), Br1-Pd1-N3 90.48(18), Br2-Pd1-C1 85.8(2), Br2-Pd1-N3 92.75(18), C1-N1-C8 125.5(6), N1-C8-C9 113.2(8), O1-C9-C8 111.1(11), C1-N2-C10 125.9(6), N2-C10-C11 112.8(7), N4-C19-C20 113.6(7), O2-C20-C19 110.4(12).

bis(NHC)Pd(II) complexes. In the ${ }^{13} \mathrm{C}$ NMR spectra, the $\mathrm{Pd}-\mathrm{C}_{\text {carbene }}$ resonances of the bis(NHC)Pd(II) complexes appeared highly downfield shifted at $\delta$ 178.9-180.9, 181.3-182.0, 189.8-190.0, 180.3-180.7, 181.0-181.2, 180.9-182.3 and 181.8-181.9 ppm for 2a-g, respectively. It was observed that the chemical shifts of carbene peaks in the ${ }^{13} \mathrm{C}$ NMR spectra of the $N$-coordinate-Pd(II)(NHC) complexes $\mathbf{1 a - b}$ and the bis(NHC)Pd(II) complexes $\mathbf{2} \mathbf{a}-\mathbf{g}$ were different. FT-IR data clearly indicated the presence of $v(\mathrm{CN})$ (for $\mathrm{C}_{\text {carbene }}$ ) at 1458 and 1448 of $\mathrm{v}(\mathrm{CN})$ (for $\mathrm{C}_{\mathrm{NHCprecursor}}$ ) at 1517 and $1517 \mathrm{~cm}^{-1}$ for the $N$-coordinate$\mathrm{Pd}(\mathrm{II})(\mathrm{NHC})$ complexes (1a-b), respectively. The FTIR data clearly indicated the presence of $v(\mathrm{CN})$ (for $\left.\mathrm{C}_{\text {carbene }}\right)$ at 1400 and $1416 \mathrm{~cm}^{-1}$ for the $N$-coordinate$\mathrm{Pd}(\mathrm{II})(\mathrm{NHC})$ complexes (1a-b), respectively. The FTIR data clearly indicated the presence of $v(\mathrm{CN})$ at 1403, 1411, 1401, 1410, 1407, 1399 and $1396 \mathrm{~cm}^{-1}$ for the bis(NHC)Pd(II) complexes (2a-g), respectively. The FT-IR data clearly indicated the presence of $v(\mathrm{OH})$ at 3412, 3404, 3381, 3423, 3404, 3404, 3430,3423 and $3457 \mathrm{~cm}^{-1}$ for all complexes (1a-b) and $(\mathbf{2} \mathbf{a}-\mathbf{g})$, respectively. The results of the elemental analysis, which is one of the analytical techniques used to prove the synthesis of compounds, were evaluated and it was observed that the calculated values were very close to the found values. These spectroscopic data are consistent with the literature. ${ }^{41}$ In this study, the single crystal of the synthesized novel $\mathrm{N}$-coordinate-Pd(II)(NHC) complex $\mathbf{1 b}$ was obtained by the
X-ray diffraction method. Thus, the structure of the complex $\mathbf{1 b}$ was confirmed.

\subsection{Structural description of $1 b$}

Complex $\mathbf{1 b}$ crystallizes in the triclinic crystal system with $P \overline{1}$ space group. Figure 1 presents the molecular and crystal structure of the complex along with the number of the atoms. The palladium centre has a typical square planar geometry with a slight tetrahedral distortion. The environment of the metal centre consists of two bromide atoms in the transpositions and two NHC ligands, coordinated to the palladium via nitrogen and carbon atoms. Also, two disordered hydroxyethyl groups are bound to the NHC ligands. Trans angles [176.73(4) and 177.9(3) $\left.{ }^{\circ}\right]$ around the $\mathrm{Pd}$ atom prove the distortion from the regular square planar coordination. The $\mathrm{PdBr}_{2} \mathrm{CN}$ coordination plane is almost planar with an r.m.s. deviation of $0.018 \AA$. The $\mathrm{Pd}-\mathrm{Br}$ distances are compatible with the many other trans- $\mathrm{PdBr}_{2}$ complexes. $^{28,49-51}$

In the crystal structure of the complex, molecules connect to each other through the intermolecular $\mathrm{C} 18$ $\mathrm{H} 18 \ldots \mathrm{O} 1^{\mathrm{i}}$ hydrogen bonds to form an infinite chain along the $a$-axis. On the $c$ axis, molecules stack as sheets via the $\mathrm{C} 15-\mathrm{H} 15 . . . \mathrm{O} 2^{\mathrm{ii}}$ hydrogen bonding interactions. The intramolecular $\mathrm{O} 1-\mathrm{H} 1$...Br2 hydrogen bond is also responsible for the stabilization of the 
Table 2. The intra- and intermolecular hydrogen bonds of the complex $\mathbf{1 b}\left(\AA{ }^{\circ}{ }^{\circ}\right)$.

\begin{tabular}{|c|c|c|c|c|}
\hline D-H $\cdots \mathbf{A}$ & D-H & $\mathbf{H} \cdots \mathbf{A}$ & $\mathbf{D} \cdots \mathbf{A}$ & D-H $\cdots A$ \\
\hline $\mathrm{O} 1-\mathrm{H} 1 \cdots \mathrm{Br} 2$ & 0.82 & 2.71 & $3.434(14)$ & 148 \\
\hline $\mathrm{C} 18-\mathrm{H} 18 \cdots \mathrm{O} 1^{\mathrm{i}}$ & 0.93 & 2.59 & $3.438(17)$ & 151 \\
\hline $\mathrm{C} 15-\mathrm{H} 15 \cdots \mathrm{O} 2^{\mathrm{ii}}$ & 0.93 & 2.78 & $3.706(14)$ & 175 \\
\hline
\end{tabular}

Symmetry codes: (i) $1+\mathrm{x}, \mathrm{y}, \mathrm{z}$; (ii) $1-\mathrm{x},-\mathrm{y}, 1-\mathrm{z}$.

crystal structure (Table 2). Within the sheets, by means of these hydrogen-bonding interactions $R_{6}^{6}(32)$, $R_{4}^{4}(36), R_{2}^{2}(16), \mathrm{S}(8)$ loops and $\mathrm{C}(7), \mathrm{C}(9)$ chains are apparent in Figure 2. ${ }^{51}$

\subsection{Proposed catalytic cycle for $\mathrm{N}$-coordinate- \\ $P d(I I)(N H C)$ and Bis(NHC)Pd(II) complexes}

The proposed general catalytic cycle is illustrated in Scheme 3. In here, the catalytic cycle begins with preactivation of the complex. Firstly, the oxidative addition of the aryl chloride/bromide to the pre-activated complex takes place. Then, the ligand exchange occurs by using the base $\left(\mathrm{K}_{2} \mathrm{CO}_{3}\right)$. In this step is considerable the character of the base. Then, 2- $n$-butylfuran or 2-nbutylthiophene molecules are added to the Pd-(NHC) complexes for activation of $\mathrm{C}-\mathrm{H}$ at position 5. Finally, C5-arylated furan/thiophene product has been obtained by the result of reductive elimination. In the final step, the steric bulk of the Pd-(NHC) complex facilitates the formation of the arylated furan/thiophene product. ${ }^{53,54}$

The electronic properties of $\mathrm{Pd}-(\mathrm{NHC})$ complexes have been provided by the alkyl substituents attached to the $\mathrm{N}$ atom. This effect provides the stability of the occurring complex in the catalytic cycle. Also, the steric bulk of the ligand facilitates the reductive elimination in the catalytic cycle. In this study; the catalytic activities of bis(NHC)Pd(II) complexes were higher than the catalytic activities of $\mathrm{N}$-coordinate$\mathrm{Pd}(\mathrm{II})(\mathrm{NHC})$ complexes due to the steric bulk of bis(NHC)Pd(II) complexes that it may facilitate reductive elimination in the catalytic cycle.

\subsection{Direct arylation of 2-n-butylfuran and 2-n- butylthiophene with various aryl halides}

All complexes (1a-b and $\mathbf{2 a - g}$ ) that contain 2-hydroxyethyl substituent may increase the solubility in the polar solvent (DMAc). Moreover, the electronic effects of the hydroxyl $(\mathrm{OH})$ group may increase the

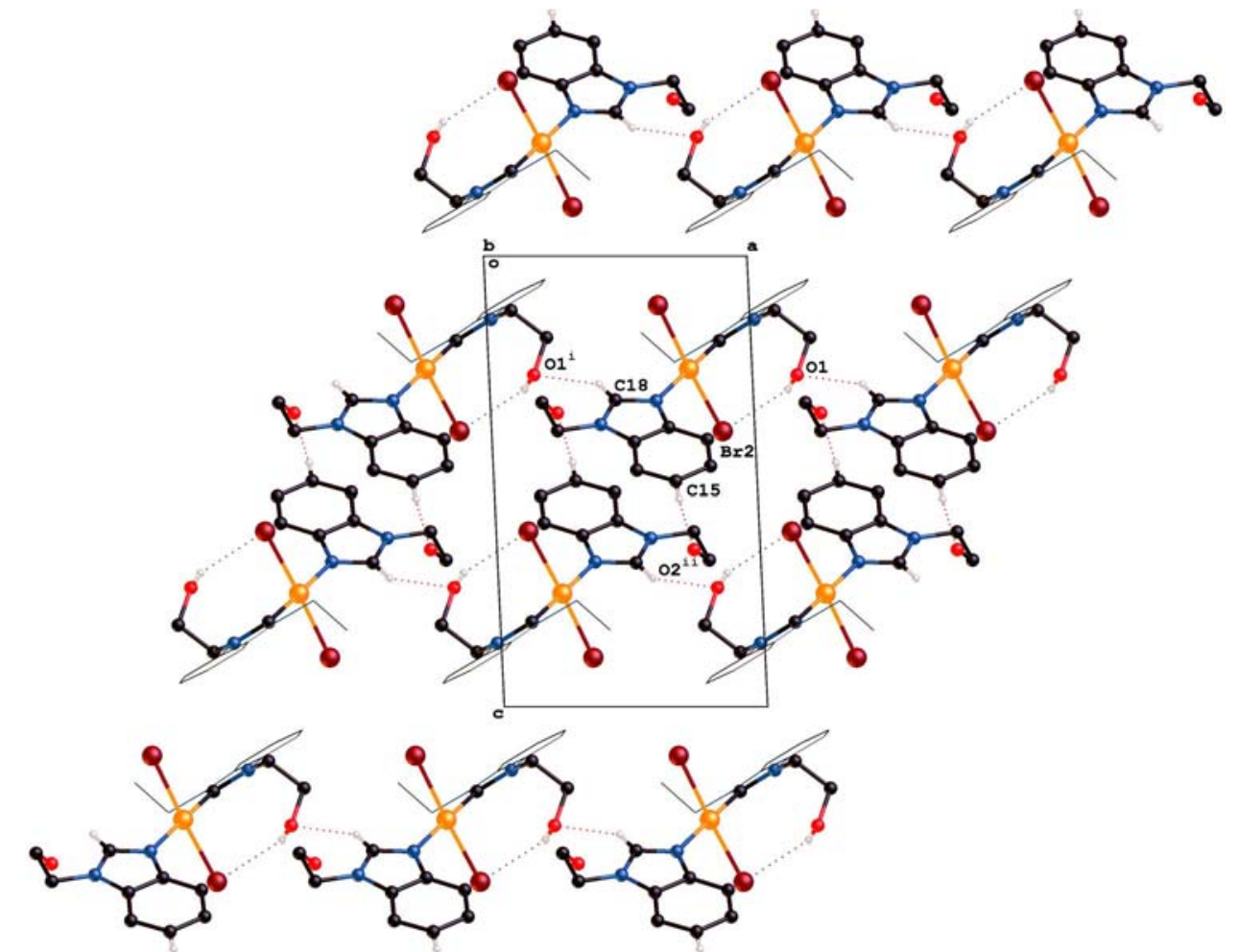

Figure 2. Graphical representation of the stacking molecules for trans-dibromoPd(II) complex $\mathbf{1 b}$. The environment of the metal center and the atoms, which play a role on the graph-set motifs are drawn as ball and stick style, while the rest are as wireframe drawing style. For the sake of clarity, hydrogen atoms not involved in bonding are omitted. 


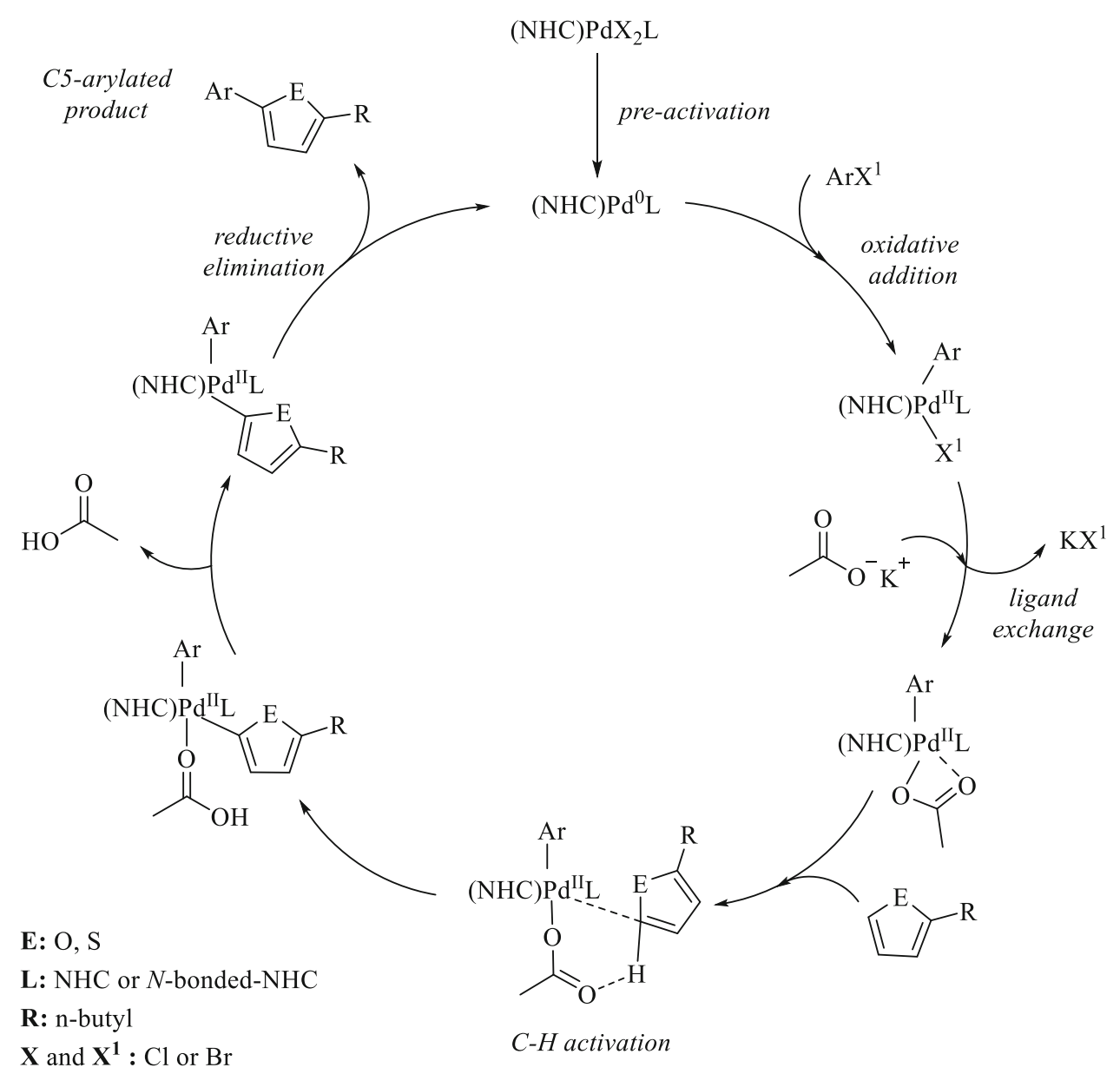

Scheme 3. Proposed catalytic cycle for the direct C-H bond arylation for N-coordinate-Pd(II)(NHC) and bis(NHC)Pd(II) Complexes.

stability of the intermediate formed by the ligand exchange in the catalytic cycle (Scheme 3 ). Thus, we can think that both properties increase the catalytic activity of complexes.

We have examined the direct arylation reactions of para-substituted aryl halides (chloride/bromide) with 2-n-butylfuran and 2-n-butylthiophene in the presence of the $N$-coordinate-Pd(II)(NHC) complexes 1a-b and the bis(NHC)Pd(II) complexes $\mathbf{2 a - g}$ as catalysts. Firstly, we examined the reaction of 2 - $n$-butylfuran with 4-bromoacetophenone and 4-bromoanisole by using complexes $\mathbf{1 a}-\mathbf{b}$ and $\mathbf{2} \mathbf{a}-\mathbf{g}$ as the catalysts. When the effects of $\mathbf{1 a}-\mathbf{b}$ in the formation of the products $\mathbf{3}$ and 4 were analyzed, the conversions were observed at $91-97 \%$ and $62-63 \%$ respectively (Table 3 ). When the effects of $\mathbf{2 a - g}$ in the formation of the products $\mathbf{3}$ and 4 were analyzed, the conversions were observed at 95-99\% and $75-98 \%$ respectively (Table 3 ). The bis(NHC)Pd(II) complexes $\mathbf{2 a - g}$ demonstrated higher conversions than the $\mathrm{N}$-coordinate-Pd(II)(NHC) complexes 1a-b. When the bis(NHC)Pd(II) complexes 2a$\mathbf{g}$ are used as the catalyst, the desired product $\mathbf{3}$ was obtained in the excellent conversion in the arylation reaction of 2-n-butyl furan with 4-bromoacetophenone. But, the conversions obtained from the reaction of 4-bromoanisole with 2- $n$-butylfuran are lower for the arylation product 4 (Table 3 ). When the $N$-coordinate-Pd(II)(NHC) complexes 1a-b were compared with them, the conversions for the product $\mathbf{3}$ were higher while the conversions for the products 4 were obtained lower (Table 3). These results show the electron-withdrawing group $\left(-\mathrm{COCH}_{3}\right)$ exhibits higher conversions than the electron-donating group $\left(-\mathrm{OCH}_{3}\right)$ in the para position (Table 3).

Secondly, the arylation reaction of 2- $n$-butylthiophene with 4-bromoacetophenone and 4-bromoanisole were examined by using all complexes $\mathbf{1 a}-\mathbf{b}$ and $\mathbf{2 a}-\mathbf{g}$ as the catalyst. When the effects of $\mathbf{1 a - c}$ in the formation of the products 5 and $\mathbf{6}$ were analyzed, the conversions were observed at $89-91 \%$ and $63-69 \%$ respectively (Table 4). When the effects of $\mathbf{2 a - g}$ in the formation of the products $\mathbf{5}$ and $\mathbf{6}$ were analyzed, the conversions were observed at $87-99 \%$ and $66-93 \%$ respectively (Table 4). When the $N$-coordinate- 
Table 3. $N$-coordinate-Pd(II)(NHC) complexes (1a-b) and bis(NHC)Pd(II) complexes (2a-g) catalyzed direct arylation of 2-n-butylfuran by using aryl bromides.

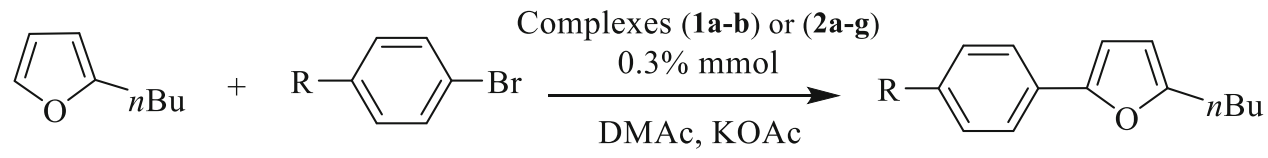

$1 \mathrm{~h}, 130{ }^{0} \mathrm{C}$

\begin{tabular}{|c|c|c|c|c|}
\hline Entry & $\mathbf{R}$ & Product & Cat. & \% Conv. \\
\hline 1 & & & $1 a$ & 91 \\
\hline 2 & & & $1 b$ & 97 \\
\hline 3 & & & $2 a$ & 95 \\
\hline 4 & & & $2 b$ & $>99$ \\
\hline 5 & $-\mathrm{COCH}_{3}$ & & $2 c$ & $>99$ \\
\hline 6 & & 3 & $2 d$ & $>99$ \\
\hline 7 & & & $2 e$ & $>99$ \\
\hline 8 & & & $2 f$ & $>99$ \\
\hline 9 & & & $2 \mathrm{~g}$ & $>99$ \\
\hline 10 & & & $1 a$ & 63 \\
\hline 11 & & & $1 b$ & 62 \\
\hline 12 & & & $2 a$ & 75 \\
\hline 13 & & & $2 b$ & 94 \\
\hline 14 & $-\mathrm{OCH}_{3}$ & & $2 c$ & 79 \\
\hline 15 & & 4 & $2 d$ & 82 \\
\hline 16 & & & $2 e$ & 98 \\
\hline 17 & & & $2 f$ & 78 \\
\hline 18 & & & $2 g$ & 77 \\
\hline
\end{tabular}

Reaction conditions: $2-n$-butylfuran $(2 \mathrm{mmol})$, aryl bromide ( $1 \mathrm{mmol}), N$-coordinate-Pd(II)(NHC) complexes (1a-b) or bis(NHC)Pd(II) complexes (2a-g) $(0.3 \% \mathrm{mmol}), \mathrm{KOAc}(1 \mathrm{mmol}), \mathrm{DMAc}(2 \mathrm{~mL}), 130{ }^{\circ} \mathrm{C}, 1$ $\mathrm{h}$, product purity was checked by GC and NMR, conversions were calculated according to aryl bromide.

$\mathrm{Pd}(\mathrm{II})(\mathrm{NHC})$ complexes $\mathbf{1 a}-\mathbf{b}$ are used as the catalysts, better conversions were obtained in the arylation reaction of 4-bromoacetophenone and 2-n-butylthiophene. When the bis(NHC)Pd(II) complexes $\mathbf{2 a - g}$ are used as the catalysts, excellent conversions were obtained in the arylation reaction of 4-bromoacetophenone and 2-nbutylthiophene (Table 4). But, the conversions obtained from the reaction of 4-bromoanisole with 2-nbutylthiophene for all complexes $\mathbf{1 a}-\mathbf{b}$ and $\mathbf{2 a - g}$ are lower in the arylation products (Table 4). These results show that the electron-withdrawing group $\left(-\mathrm{COCH}_{3}\right)$ exhibits higher conversions than the electron-donating group $\left(-\mathrm{OCH}_{3}\right)$ in the para position (Table 4). The bis(NHC)Pd(II) complexes $\mathbf{2 a - g}$ showed higher conversions than the $N$-coordinate-Pd(II)(NHC) complexes 1a-b. In general, 2-n-butylfuran exhibited higher conversions than 2-n-butylthiophene with the same aryl bromide (Table 3, 4). 
Table 4. $\quad N$-coordinate-Pd(II)(NHC) complexes (1a-b) and bis(NHC)Pd(II) complexes (2a-g) catalyzed direct arylation of 2- $n$-butylthiophene by using aryl bromides.

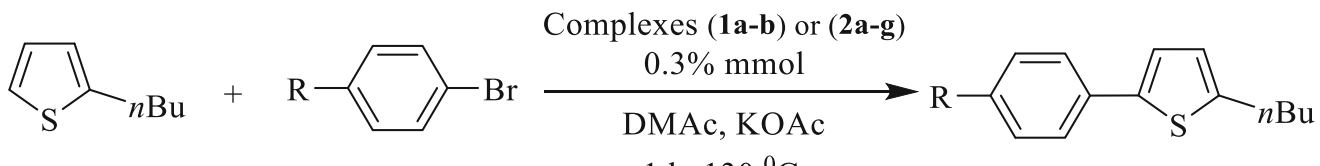

$1 \mathrm{~h}, 130{ }^{\circ} \mathrm{C}$

\begin{tabular}{|c|c|c|c|c|}
\hline Entry & $\mathbf{R}$ & Product & Cat. & \% Conv. \\
\hline 1 & & & $1 a$ & 89 \\
\hline 2 & & & $1 b$ & 91 \\
\hline 3 & & & $2 \mathbf{a}$ & 87 \\
\hline 4 & & & $2 b$ & $>99$ \\
\hline 5 & $-\mathrm{COCH}_{3}$ & & $2 c$ & $>99$ \\
\hline 6 & & 5 & $2 d$ & $>99$ \\
\hline 7 & & & $2 e$ & 98 \\
\hline 8 & & & $2 f$ & $>99$ \\
\hline 9 & & & $2 \mathrm{~g}$ & $>99$ \\
\hline 10 & & & $1 \mathrm{a}$ & 63 \\
\hline 11 & & & $1 b$ & 69 \\
\hline 12 & & & $2 \mathbf{a}$ & 66 \\
\hline 13 & & & $2 b$ & 74 \\
\hline 14 & $-\mathrm{OCH}_{3}$ & & $2 c$ & 86 \\
\hline 15 & & 6 & $2 d$ & 83 \\
\hline 16 & & & $2 e$ & 76 \\
\hline 17 & & & $2 f$ & 93 \\
\hline 18 & & & $2 g$ & 78 \\
\hline
\end{tabular}

Reaction conditions: $2-n$-butylthiophene $(2 \mathrm{mmol})$, aryl bromide $(1 \mathrm{mmol}), \mathrm{N}$-coordinate-Pd(II)(NHC) complexes (1a-b) or bis(NHC)Pd(II) complexes $(\mathbf{2 a - g})(0.3 \% \mathrm{mmol}), \mathrm{KOAc}(1 \mathrm{mmol})$, DMAc $(2 \mathrm{~mL}), 130$ ${ }^{\circ} \mathrm{C}, 1 \mathrm{~h}$, product purity was checked by GC and NMR, conversions were calculated according to aryl bromide.

Finally, when alkyl/aryl chloride used, the conversion of arylation product was obtained less than alkyl/aryl bromide (Table 5, 6). The experiments were carried out with the $N$-coordinate-Pd(II)(NHC) complex $\mathbf{1 b}$ and the bis(NHC)Pd(II) complex 1e at $16 \mathrm{~h}$. We examined the arylation reaction of 2-n-butylfuran with 4-chloroacetophenone and 4-chloroanisole by using the complexes $\mathbf{1 b}$ and $\mathbf{2 e}$ as the catalyst. When the effect of the $N$-coordinate-Pd(II)(NHC) complex $\mathbf{1 b}$ was analyzed in the formation of the product $\mathbf{3}$ and $\mathbf{4}$, the conversions were observed at $89 \%$ and $63 \%$, respectively (Table 5). When the effect of the bis(NHC)Pd(II) complex $2 \mathbf{e}$ was analyzed in the formation of the product $\mathbf{3}$ and $\mathbf{4}$, the conversions were observed at $99 \%$ and $68 \%$, respectively (Table 5). When the effect of the $\mathrm{N}$-coordinate-Pd(II)(NHC) 
Table 5. $\quad N$-coordinate-Pd(II)(NHC) complex $\mathbf{1 b}$ and bis(NHC)Pd(II) complex 2e catalyzed direct arylation of 2-n-butylfuran by using aryl chlorides.

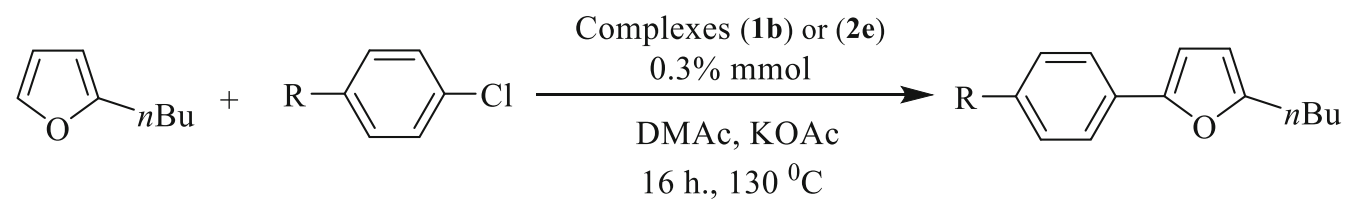

\begin{tabular}{|c|c|c|c|c|}
\hline Entry & $\mathbf{R}$ & Product & Cat. & \% Conv. \\
\hline 1 & $-\mathrm{COCH}_{3}$ & & $1 b$ & 89 \\
\hline \multirow[t]{2}{*}{2} & $-\mathrm{COCH}_{3}$ & & $2 e$ & 99 \\
\hline & & 3 & & \\
\hline 3 & $-\mathrm{OCH}_{3}$ & & $1 b$ & 63 \\
\hline \multirow[t]{2}{*}{4} & $-\mathrm{OCH}_{3}$ & & $2 e$ & 68 \\
\hline & & 4 & & \\
\hline
\end{tabular}

Reaction conditions: 2 - $n$ - butylfuran $(2 \mathrm{mmol})$, aryl bromide $(1 \mathrm{mmol}), N$-coordinate-Pd(II)(NHC) complex (1b) or bis(NHC)Pd(II) complex (2e) $(0.3 \% \mathrm{mmol})$, KOAc $(1 \mathrm{mmol})$, DMAc $(2 \mathrm{~mL}), 130{ }^{\circ} \mathrm{C}, 16 \mathrm{~h}$, product purity was checked by GC and NMR, conversions were calculated according to aryl chloride.

Table 6. $N$-coordinate-Pd(II)(NHC) complex $\mathbf{1 b}$ and bis(NHC)Pd(II) complex 2e catalyzed direct arylation of 2-n-butylthiophene by using aryl chlorides.

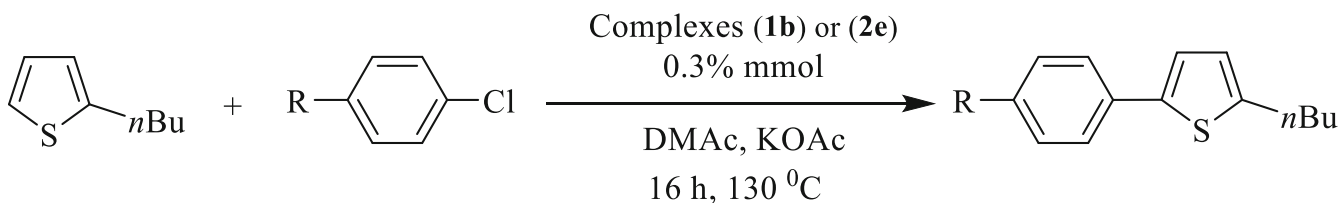

\begin{tabular}{ccccc}
\hline Entry & $\mathbf{R}$ & Product & Cat. & \% Conv. \\
\hline $\mathbf{1}$ & $-\mathrm{COCH}_{3}$ & $\mathbf{1 b}$ & 54 \\
$\mathbf{3}$ & $-\mathrm{COCH}_{3}$ & $\mathbf{2 e}$ & 41 \\
$\mathbf{4}$ & $-\mathrm{OCH}_{3}$ & $\mathbf{2 e}$ & 51 \\
& &
\end{tabular}

Reaction conditions: 2- $n$-butylthiophene $(2 \mathrm{mmol})$, aryl bromide $(1 \mathrm{mmol}), N$-coordinate-Pd(II)(NHC) complex (1b) or bis(NHC)Pd(II) complex (2e) $(0.3 \% \mathrm{mmol})$, KOAc $(1 \mathrm{mmol})$, DMAc $(2 \mathrm{~mL}), 130{ }^{\circ} \mathrm{C}, 16 \mathrm{~h}$, product purity was checked by GC and NMR, conversions were calculated according to aryl chloride. 
complex 1b was analyzed in the formation of the product 5 and $\mathbf{6}$, the conversions were observed at $54 \%$ and $41 \%$, respectively (Table 5 ). When the effect of the bis(NHC)Pd(II) complex 2e was analyzed in the formation of the product $\mathbf{5}$ and $\mathbf{6}$, the conversions were observed at $67 \%$ and $51 \%$, respectively (Table 6). When chlorinated substrates are used, it has become even more pronounced difference between the arylation reaction involving 2-n-butylfuran and 2- $n$ butylthiophene compounds. The synthesized complexes have been highly active catalysts in our study when compared to the similar studies related to bis(NHC)Pd(II) complexes published. ${ }^{43}$, 55-62

\section{Conclusions}

As a result, we reported the synthesis of the two $\mathrm{N}$ coordinate-Pd(II)(NHC) complexes $\mathbf{1 a - b}$ and the seven 2-hydroxyethyl substituted bis(NHC)Pd(II) complexes 2a-g. All complexes (1a-b and $\mathbf{2 a}-\mathbf{g})$ were prepared from the 2-hydroxyethyl substituted NHC precursors and palladium acetate. The catalytic activity of these complexes (1a-b and $\mathbf{2 a - g}$ ) have been investigated that they are more efficient and stable catalysts for the direct arylation reactions of 2 -n-butylfuran and 2-n-butylthiophene with aryl chloride/bromide. The molecular and crystal structure of the complex $1 \mathrm{~b}$ is determined by single-crystal $\mathrm{X}$-ray diffraction method. X-ray structural analysis shows that the metal coordination environment of the complex features slightly distorted square planar geometry, in which the $\mathrm{C}$ - and N-bounded NHC ligands, and the bromide atoms are trans to each other.

\section{Supplementary Information (SI)}

Crystallographic data as .cif files for the structures reported in this paper have been deposited at the Cambridge Crystallographic Data Center with CCDC 1888300 for $\mathbf{1 b}$. Copies of the data can be obtained free of charge at http:// www.ccdc.cam.ac.uk/conts/retrieving.html or from the Cambridge Crystallographic Data Center, 12, Union Road, Cambridge CB2 1EZ, UK. Fax: (+44) 1223-336-033, email: deposit@ccdc.cam.ac.uk.

\section{Acknowledgements}

The authors acknowledge Dokuz Eylul University for the use of the Oxford Rigaku Xcalibur Eos Diffractometer (purchased under University Research Grant No: 2010.KB.FEN.13). The authors thank the Inonu University Faculty of Science Department of Chemistry for the spectroscopy and characterization of compounds.

\section{Compliance with ethical standards}

Conflicts of interest There are no conflicts of interest to declare.

\section{References}

1. (a) Wanzlick H-W and Schönherr H-J 1968 Direct synthesis of a mercury salt-carbene complex Angew. Chem. Int. Ed. Engl. 7 141; (b) Öfele K 1968 1,3Dimethyl-4-imidazolinyliden-(2)-pentacarbonylchrom ein neuer Übergangsmetall-carben-komplex J. Organomet. Chem. 1242

2. Arduengo III J, Harlow R L and Kilne M 1991 A stable crystalline carbene J. Am. Chem. Soc. 113361

3. Hahn F E and Jahnke M C 2008 Heterocyclic carbenes: synthesis and coordination chemistry Angew. Chem. Int. Ed. 473122

4. Lazreg F, Nahra F and Cazin C S J 2015 Copper-NHC complexes in catalysis Coord. Chem. Rev. 29348

5. Hopkinson M N, Richter C, Schedler M and Glorius F 2014 An overview of N-heterocyclic carbenes Nature 510485

6. Diez-Gonzalez S, Marion N and Nolan S P 2009 $\mathrm{N}$-heterocyclic carbenes in late transition metal catalysis Chem. Rev. 1093612

7. Nelson D J 2015 Accessible syntheses of late transition metal (Pre) catalysts bearing n-heterocyclic carbene ligands Eur. J. Inorg. Chem. 122012

8. Benhamou L, Chardon E, Lavigne G, Bellemin-Laponnaz S and Cesar V 2011 Synthetic routes to N-heterocyclic carbene precursors Chem. Rev. 1112705

9. Grundemann S, Kovacevic A, Albrecht M, Faller J W and Crabtree R H 2001 Abnormal binding in a carbene complex formed from an imidazolium salt and a metal hydride complex Chem. Commun. 212274

10. Schuster O, Yang L, Raubenheimer H G and Albrecht M 2009 Beyond conventional N-heterocyclic carbenes: abnormal, remote, and other classes of NHC ligands with reduced heteroatom stabilization Chem. Rev. 109 3445

11. Albrecht M 2008 C4-bound imidazolylidenes: from curiosities to high-impact carbene ligands Chem. Commun. 313601

12. Droge T and Glorius F 2010 The Measure of All Rings-N-Heterocyclic Carbenes Angew. Chem. Int. Ed. 496940

13. Nelson D J and Nolan S P 2013 Quantifying and understanding the electronic properties of N-heterocyclic carbenes Chem. Soc. Rev. 426723

14. Budagumpi S, Haque R A and Salman A W 2012 Stereochemical and structural characteristics of singleand double-site $\mathrm{Pd}(\mathrm{II})-\mathrm{N}$-heterocyclic carbene complexes: Promising catalysts in organic syntheses ranging from CC coupling to olefin polymerizations Coord. Chem. Rev. 2561787

15. Kuhl O 2007 The chemistry of functionalised N-heterocyclic carbenes Chem. Soc. Rev. 36592

16. Trzeciak A M and Ziolkowski J J 2005 Structural and mechanistic studies of Pd-catalyzed CC bond 
formation: The case of carbonylation and Heck reaction Coord. Chem. Rev. 2492308

17. Aktaş A and Gök Y 2014 4-Vinylbenzyl-substituted silver(I) N-heterocyclic carbene complexes and ruthenium(II) N-heterocyclic carbene complexes: synthesis and transfer hydrogenation of ketones Transit. Met. Chem. 39925

18. Aktaş A and Gök Y 2015 N-Propylphthalimide-Substituted Silver(I) N-Heterocyclic Carbene Complexes and Ruthenium(II) N-Heterocyclic Carbene Complexes: Synthesis and Transfer Hydrogenation of Ketones Catal. Lett. 145631

19. Aktaş A, Barut Celepci D, Gök Y and Aygün M 2018 2-Hydroxyethyl-Substituted Pd-PEPPSI Complexes: Synthesis, Characterization and the Catalytic Activity in the Suzuki-Miyaura Reaction for Aryl Chlorides in Aqueous Media ChemistrySelect 39974

20. Gök Y, Aktaş A, Sarı Y and Erdoğan H 2019 2-methyl1,4-benzodioxan-substituted bis(NHC)PdX2 complexes: Synthesis, characterization and the catalytic activity in the direct arylation reaction of some 2-alkylheterocyclic compounds J. Iran. Chem. Soc. 16423

21. Aktaş A, Erdemir F, Barut Celepci D, Gök Y and Aygün M 2019 Mixed phosphine/N-heterocyclic carbene-palladium complexes: synthesis, characterization, crystal structure and application in the Sonogashira reaction in aqueous media Transit. Met. Chem. 44229

22. Aktaş A, Taslimi P, Gök Y and Gülçin İ 2017 Novel NHC Precursors: Synthesis, Characterization, and Carbonic Anhydrase and Acetylcholinesterase Inhibitory Properties Arch. Pharm. Chem. Life Sci. 350 e201700045

23. Sarı Y, Aktaş A, Taslimi P, Gök Y and Gülçin İ 2017 Novel N-propylphthalimide- and 4-vinylbenzyl-substituted benzimidazole salts: Synthesis, characterization, and determination of their metal chelating effects and inhibition profiles against acetylcholinesterase and carbonic anhydrase enzymes J. Biochem. Mol. Toxicol. 32 e 22009

24. Erdemir F, Barut Celepci D, Aktaş A, Taslimi P, Gök Y, Karabiyık H and Gülçin I 2018 2-Hydroxyethyl substituted NHC precursors: Synthesis, characterization, crystal structure and carbonic anhydrase, $\alpha$-glycosidase, butyrylcholinesterase, and acetylcholinesterase inhibitory properties J. Mol. Struct. 1155797

25. Türker F, Barut Celepci D, Aktaş A, Taslimi P, Gök Y, Aygün M and Gülçin İ 2018 meta-Cyanobenzyl substituted benzimidazolium salts: Synthesis, characterization, crystal structure and carbonic anhydrase, $\alpha-$ glycosidase, butyrylcholinesterase, and acetylcholinesterase inhibitory properties Arch. Pharm. Chem. Life Sci. 3511800029

26. Behçet A, Çağlılar T, Barut Celepci D, Aktas A, Taslimi P, Gök Y, Aygün M, Kaya R and Gülçin İ 2018 Synthesis, characterization and crystal structure of 2-(4-hydroxyphenyl)ethyl and 2-(4-nitrophenyl)ethyl Substituted Benzimidazole Bromide Salts: Their inhibitory properties against carbonic anhydrase and acetylcholinesterase J. Mol. Struct. 1170160

27. Aktas A, Abbas Ali Noma S, Barut Celepci D, Erdemir F, Gök Y and Ateş B 2019 New 2-hydroxyethyl substituted N-Heterocyclic carbene precursors: Synthesis, characterization, crystal structure and inhibitory properties against carbonic anhydrase and xanthine oxidase J. Mol. Struct. 1184487

28. Aktaş A, Barut Celepci D, Kaya R, Taslimi P, Gök Y, Aygün M and Gülçin İ 2019 Novel morpholine liganded Pd-based N-heterocyclic carbene complexes: synthesis, characterization, crystal structure, antidiabetic and anticholinergic properties Polyhedron 159345

29. Kaloğlu M, Kaloğlu N and Özdemir İ 2018 Direct C-H Bond Activation of Benzoxazole and Benzothiazole with Aryl Bromides Catalyzed by Palladium(II)-Nheterocyclic Carbene Complexes Chin. J. Chem. 36 837

30. Kaloğlu M and Özdemir İ 2018 Palladium(II)-NHeterocyclic Carbene Complexes: Efficient Catalysts for the Direct C-H Bond Arylation of Furans with Aryl Halides Appl. Organomet. Chem. 32 e4399

31. Kaloğlu M and Özdemir İ 2018 Palladium (II)-Nheterocyclic carbene-catalyzed direct C2-or C5-arylation of thiazoles with aryl bromides Tetrahedron $\mathbf{7 4}$ 2837

32. Han Y, Hong Y-T and Huynh H V 2008 Ag (I) and Pd (II) complexes of a 1, 3-dibenzhydryl substituted benzannulated N-heterocyclic carbene: Unexpected rearrangement, structures and catalytic studies $J$. Organomet. Chem. 6933159

33. Landaeta V R, Rodríguez-Lugo R E, Rodríguez-Arias E N, Coll-Gómez D S and González T 2010 Studies on the coordination chemistry of methylated xanthines and their imidazolium salts. Part 1: benzyl derivatives Trans. Met. Chem. 35165

34. Aktaş A, Akkoç S and Gök Y 2013 Palladium catalyzed Mizoroki-Heck and Suzuki-Miyaura reactions using naphthalenomethyl-substituted imidazolidin-2ylidene ligands in aqueous media J. Coord. Chem. 66 2901

35. del Pozo J, Salas G, Álvarez R, Casares JA and Espinet Pablo 2016 The Negishi Catalysis: Full Study of the Complications in the Transmetalation Step and Consequences for the Coupling Products Organometallics 353604

36. Cordovilla C, Bartolomé C, Ma Martínez-Ilarduya J and Espinet P 2015 The Stille Reaction, 38 Years Later ACS Catal. 53040

37. Mitsui T, Sugihara M, Tokoro Y and Fukuzawa S 2015 Synthesis of adamantyl substituted 1,2,3-triazol-5-ylidene ligands and their PEPPSI-type palladium complexes Tetrahedron $\mathbf{7 1} 1509$

38. Thankachan A P, Sindhu K S, Ujwaldev S M and Anilkumar G 2017 Synthesis of substituted benzofurans and indoles by $\mathrm{Zn}$-catalyzed tandem Sonogashiracyclization strategy Tetrahedron Lett. 58536

39. Valente C, Calimsiz S, Hoi K H, Mallik D, Sayah M and Organ M G 2012 The development of bulky palladium nhc complexes for the most-challenging crosscoupling reactions Angew. Chem. Int. Ed. 513314

40. Winkler A, Brandhorst K, Freytag M, Jones P G and Tamm M 2016 Palladium(II) complexes with anionic $\mathrm{N}$-heterocyclic carbene-borate ligands as catalysts for the amination of aryl halides Organometallics 351160

41. Sarı Y, Aktaş A, Barut Celepci D, Gök Y and Aygün M 2017 Synthesis, Characterization and Crystal Structure of New 2-Morpholinoethyl-Substituted Bis-(NHC)Pd(II) 
Complexes and the Catalytic Activity in the Direct Arylation Reaction Catal. Lett. 1472340

42. Erdoğan H, Aktaş A, Gök Y and Sarı Y 2017 N-Propylphthalimide-substituted bis-(NHC)PdX2 complexes: synthesis, characterization and catalytic activity in direct arylation reactions Transit. Met. Chem. 4331

43. Gök Y, Aktaş A, Erdoğan H and Sarı Y 2018 New 4-vinylbenzyl-substituted bis(NHC)-Pd(II) complexes: Synthesis, characterization and the catalytic activity in the direct arylation reaction Inorg. Chim. Acta $\mathbf{4 7 1} 735$

44. CrysAlis ${ }^{\text {Pro }}$ Software System, Version 1.171.38.43, Rigaku Corporation 2015 Oxford UK

45. Clark RC and Reid J S 1995 The analytical calculation of absorption in multifaceted crystals Acta Cryst. A51 887

46. Dolomanov O V, Bourhis L J, Gildea R J, Howard J A K and Puschmann H J 2009 OLEX2: a complete structure solution, refinement and analysis program Appl. Cryst. 42339

47. Sheldrick G M 2015 Integrating space group determination and structure solution Acta Crystallogr. A71 3

48. Sheldrick G M 2015 Crystal structure refinement with SHELXL Acta Crystallogr. C71 3

49. Hahn F E, Holtgrewe C and Pape T 2004 The Pd(II) Complex of a N,N'-Diallylbenzimidazol-2-ylidene Ligand Z. Naturforsch. 59b 1051

50. Doğan Ö, Gürbüz N, Özdemir İ, Çetinkaya B, Şahin O and Büyükgüngör O 2009 Synthesis characterization and catalytic activity of novel N-heterocyclic carbenepalladium complexes Dalton Trans. 357087

51. Bernhammer J C and Huynh H V 2012 Correlation of spectroscopically determined ligand donor strength and nucleophilicity of substituted pyrazoles Dalton Trans. 418600

52. Bernstein J, Davis RE, Shimoni L and Chang N-L 1995 Patterns in Hydrogen Bonding: Functionality and Graph Set Analysis in Crystals Angew. Chem. Int. Ed. 341555

53. García-Cuadrado D, de Mendoza P, Braga AAC, Maseras F and Echavarren A M 2007 Proton-abstraction mechanism in the palladium-catalyzed intramolecular arylation: substituent effects J. Am. Chem. Soc. 1296880
54. Gorelsky SI, Lapointe D and Fagnou K 2008 Analysis of the concerted metalation-deprotonation mechanism in palladium-catalyzed direct arylation across a broad range of aromatic substrates J. Am. Chem. Soc. 130 10848

55. Akkoç S, Gök Y, Akkurt M and Tahir M N 2014 Catalytic activities in the direct C5 arylation of novel palladium N-heterocyclic carbene complexes containing benzimidazol-2-ylidene nucleus Inorg. Chim. Acta 413221

56. Gök Y, Akkoç S, Albayrak S, Akkurt M and Tahir M N 2014 N-Phenyl-substituted carbene precursors and their silver complexes: synthesis, characterization and antimicrobial activities Appl. Organomet. Chem. 28 244

57. Xiao Z-K, Yin H-Y and Lu J-M 2014 N-Heterocyclic carbene-palladium(II)-1-methylimidazole complex catalyzed $\alpha$-arylation of symmetric dialkyl ketones with aryl chlorides Inorg. Chim. Acta 423106

58. Akkoç S and Gök Y 2015 Dichlorido(3-chloropyridineN)[1,3-dialkylbenzimidazol-2-ylidene]palladium(II) complexes: Synthesis, characterization and catalytic activity in the arylation reaction Inorg. Chim. Acta $\mathbf{4 2 9} 34$

59. Yiğit M, Yiğit B and Gök Y 2016 Synthesis of novel palladium(II) $\mathrm{N}$-heterocyclic carbene complexes and their catalytic activities in the direct C5 arylation reactions Inorg. Chim. Acta $\mathbf{4 5 3} 23$

60. Kaloğlu M, Özdemir İ, Dorcet V, Bruneau C and Doucet H 2017 PEPPSI-Type Palladium-NHC complexes: synthesis, characterization, and catalytic activity in the direct C5-Arylation of 2-substituted thiophene derivatives with aryl halides Eur. J. Inorg. Chem. 20171382

61. Yin S-C, Zhou Q, He Q-W, Li S-W, Qian P-C and Shao L-X 2017 N-Heterocyclic carbene-Pd(II)-1methylimidazole complex catalyzed $\mathrm{CH}$ bond arylation of (benzo)thiophenes with aryl chlorides Tetrahedron 73427

62. Liu Q-X, He B-Y, Qian P-C and Shao L-G 2017 $\mathrm{N}$-Heterocyclic carbene-palladium(II)-1-methylimidazole complex catalyzed direct $\mathrm{C}-\mathrm{H}$ bond arylation of imidazo[1,2-a]pyridines with aryl chlorides Org. Biomol. Chem. 151151 